\title{
Utilization of Sewage Sludge Compost in Horticulture
}

\author{
Francis R. Gouin ${ }^{1}$
}

Additional index words. polymer-dewatered, lime dewatered, container media, soil amendments, nursery, greenhouse, vegetables

Summary. Sewage sludge is being converted to compost by many municipalities. Its use in the production, establishment, and/or maintenance of horticultural crops is dependent on soluble salt concentration, particle size, stability, dewatering procedures, storage conditions, and crop needs. Soluble salt concentration has the greatest effect on the amount of compost that can be used as a soil or potting media amendment. Because composted sewage sludge is rich in plant nutrients, it can supply many of the nutrient needs of plants, depending on the amount used and if the plants are growing in the ground or in containers. However, improper storage of composted sewage sludge can render the product useless due to the accumulation of acetic acid and alcohol that occur under anaerobic conditions.

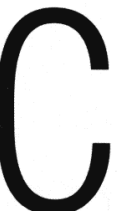

ompost made from sewage sludge (bio-solids) and woodchips or sawdust can be used to grow a wide variety of horticultural crops under field and container culture. Recent studies also indicate that compost made from sewage sludgeand municipal solid waste (MSW), better known as co-compost, also can be used as a growing medium component for growing pot plants, bedding plants, and vegetable transplants.

The US. Environmental Protection Agency (EPA) and environmental departments in most states limit composting of sewage sludges to those low in heavy metals and toxic compounds. This is to assure that the resulting compost will

Department of Horticulture, University of Maryland, College Park, MD 20742-5611.

${ }^{\prime}$ Professor. 
have wide horticultural use and can be used with a wide margin of safety.

There are a number of factors that determine the concentration of sewage sludge compost that can be used in soils and in formulating potting media (Chaney et al., 1980). These include soluble salt, particle size, stability of product, dewatering procedure used in processing sludge, nutrient concentrations in soils, crop needs, and storage conditions. It is not recommended that composted sewage sludge be used at $100 \%$ concentration for growing horticultural crops. Such high levels are likely to damage crops, or contribute to potential surface and groundwater contamination.

High soluble salt levels are likely to be the major problem associated with excess use of compost made with sewage sludge (Gouin, 1977; Gouin and Walker, 1977). It is not uncommon to measure electrical conductivity, by saturated past extract, in excess of $10 \mathrm{mmhos} / \mathrm{cm}$. Although these salts are leached easily, such levels are likely to cause instant dehydration of most root cells, especially of young seedlings. Also, compost made from sewage sludge and woodchips or sawdust has a rather low water-holding capacity as compared to peatmoss or co-compost. Therefore, it is best to follow established guidelines when using such compost as a soil amendment or potting media component.

Soluble salt concentrations are influenced by the number of times compost has been recycled as a bulking or inoculating agent in the composting process (Gouin, 1991). It is recommended that $10 \%$ finished compost be used to inoculate a fresh blend of sawdust or woodchips and sludge to hasten the composting process. Woodchips are removed during thescreening process. When used as a bulking material, abouttwo-thirds by volume are recycled. This means that one-third by volume of new woodchips are used at each loading. Woodchips removed during the screening of compost, not only serve as inoculum, but as bulking material as well. However, when bulking woodchips become scarce, it is not uncommon to usefinished compost as the bulking material. When this occurs, the resulting compost will have a higher soluble salt level.

Compost particle size greatly influences porosity and salt concentrations (Marcotrigiano et al., 1985, Wootton et al., 1981). Smaller particles result in greater surface area, thus allowing for more rapid mineralization and an increased chance for salt accumulation. Also, as particle size decreases, porosity decreases, an important consideration when using compost in formulating potting media. Particles $>1.25 \mathrm{~cm}$ not only create mechanical problems in potting, but can contribute to a $\mathrm{N}$ stress in plants, depending on the number of large particles present and the fertilizer regime being used. The major justification for having particles up to $1.25 \mathrm{~cm}$ is to improve drainage.

Before it can be used in formulating media mixes, compost made from sewage sludge must be stable (Purman and Gouin, 1992; Sanderson, 1980). After the initial 20 to 30 days of composting under controlled conditions, all available $\mathrm{N}$ is in the ammonium $\left(\mathrm{NH}_{4}^{+}\right)$form. It takes $\approx 2$ to 3 months, in static piles, to convert $\left(\mathrm{NH}_{4}^{+}\right)$to nitrate $\left(\mathrm{NO}_{3}\right)$ (Vega-Sanchez et al., 1987). Although many horticultural plants can absorb $\mathrm{NH}_{4}^{+}$, it can restrict the growth of others. Using the compost before it is stabilized also can result in media shrinkage, which can cause a severe problem, especially for plants grown in large containers.

Some methods of dewatering sludges for composting can affect seriously their use in horticulture (Korcak et al., 1979). The use of hydrated lime during the dewatering process produces compost with a $\mathrm{pH}>8.0$ and high levels of soluble salts. Adding fly ash to sludge to hasten dewatering also adds to the soluble salt problem and increases the density of the compost.

Storage conditions following the initial composting period also influence the quality of compost. Composting piles that become anaerobic produce a compost that contains acetic acid and methanol or methane (my unpublished data). In fact, storage piles of composted sewage sludge occasionally have undergone spontaneous combustion. A compost stored under anaerobic conditions also will have a pH between 3.5 and 3.0 due to the accumulation of acetic acid.

Application rates of composted sewage sludge should be based on soil test resultsand the needs of crops to be grown. Although certain crops can be grown in soils amended with excessive amounts of composted sewage sludge, the practice is not environmentally sound. With studies using high populations of forest seedlings, levels in excess of 112t-ha $a^{-1}$ often resulted in a decrease in hardwood seedling populations, but with little to no increase in top growth (Gouin and Walker, 1977). For coniferous species, compost levels in excess of $56 \mathrm{t} \cdot \mathrm{ha}^{-1}$ caused a significant decrease in seedling populations (Gouin, 1977). However, once seedlings were established, mulching coniferous seedlings with composted sewage sludge at 112 tha $a^{-1}$ stimulated growth. At these rates, there is no need to apply additional fertilizers through the first growing season.

As an ingredient in potting media, composted sewage sludge can vary from $20 \%$ to $50 \%$ by volume, depending on the species and age of plants (Falahi-Ardakani et al., 1987a). A potting media mix of one-third each by volume of peat, perlite, and compost made from sewage sludge and sieved through a $1.25-\mathrm{cm}$ mesh, will supply the $\mathrm{N}$ needs of bedding plants and vegetable transplants for 3 to 4 weeks, $\mathrm{K}$ needs for 4 to 5 weeks, $P$ needs for 6 to 8 weeks, and all essential trace elements (Falahi-Ardakani et al., 1987b, 1988b). Therefore, the use of composted sewage sludge in formulating potting media can result in substantial savings in fertilizers. It also has been observed that bedding plants and vegetable transplants grown in compost-amended mediaseem to have a better shelf life than similar plants grown in peat-lite media (my unpublished data). In the growing of hardy chrysanthemums composted sewage sludge can be used at the rate of $33 \%$ to $50 \%$ by volume with equal parts of peat and sand (Gouin, 1985). Market quality-hardy chrysanthemums plants can be produced using only $\mathrm{N}$ in the fertilizer program.

Potting media containing up to $50 \%$ by volume of composted sewage sludge also has been demonstrated to be safe for use in growing greenhouse cucumbers (Cucumis sativus $\mathrm{L}$. 'La Reine') (Falahi-Ardakani et al., 1988b). Even under media $\mathrm{pHs}$ as low as 3.8 there was no $\mathrm{Cd}$ uptake into either fruit or foliageand only minimal uptake of $\mathrm{Zn}$ by the fruit. Because it is unlikely that growers would ever attempt to produce greenhouse cucumbers at such low $\mathrm{pH}$, it indicates the safety of the product for producing food crops. Recent changes in EPA regulations on the use of clean sludges for the production of agriculture crops supports this.

Another beneficial use for compost is its disease-suppressing properties (Hoitink et al., 1991). When used immediately following stabilization as a soil or media amendment, compost has been shown to control "damping-off" organisms. Poinsettia growers report that, by using compost in their media, they no longer need fungicide drenches-confirming research results. Thus, compost not only lowers production costs but can reduce thechance of surfaceand ground pollution from soil pesticide drenches and fertilizers.

The landscape contracting industry also can benefit from using compost made from sewage sludge; e.g., for establishing turf in the absence of "topsoil" and as a backfill component when transplanting trees and shrubs (Shanks and Gouin, 1984). Its useeliminates the need to add fertilizers through the first growing season, and the residual nutrient release properties are evident for several years. It also can be used to maintain flower beds and turf when used as a top-dressing or mulch.

Several horticultural industries can benefit by recommending and using composted sewage sludge in numerous production and maintenance programs. In addition to reducing the use of chemical fertilizers and soil fungicides, composted sewage sludge also can lessen dependence on imported organic amendments. The composting and use of sewage sludge in horticulture is not only an effective means of recycling, but it simultaneously decreases our dependency on imported materials necessary for the production, establishment, and maintenance of horticultural plants.

\section{Literature Cited}

Chaney, R.L., J.B.. Munns, and H.M. Cathey. 1980. Effectiveness of digested sewage sludge compost in studying nutrients for soilless media. J. Amer. Soc. Hort. Sci. 1054485-495. 
Falahi-Ardakani, A., F.R. Gouin, J.C. Bouwkamp, and R.L. Chancy 1987a. Growth response and mineral uptake of vegetable transplants grown in a composted sewage sludgeamended medium. Part II. As influenced by time of application of $\mathrm{N}$ and K. J.Environ. Hort. 5:112-116.

Falahi-Ardakani, A., J.C. Bouwkamp, F.R. Gouin, and R.L. Chancy 1987b. Growth response and mineral uptake of vegetable transplants grown in a composted sewage sludge amended medium. Part I. Nutrient supplying power of the medium as measured by tissue analysis. J. Environ. Hort. 5:107-112.

Falahi-Ardakani A., J.C. Bouwkamp, F.R. Gouin, and R.L Chancy. 1988a. Growth response and mineral uptake of lettuce and tomato transplants grown in media amended with composted sewage sludge as influenced by fertilizer and amendments. J. Environ, Hort. 6:130-132.

Falahi-Ardakani, A., K Corey, and F.R. Gouin. 1988 b. Influence of $\mathrm{pH}$ on cadmium and zinc concentrations of cucumber grown in sewage sludge. HortScience 23:1015-1017.

Gouin, F.R. 1977. Conifer tree seedling response to nursery soil amended with composted sewage sludge. HortScience 12:341-342.

Gouin, F.R. 1985. Growth of chrysanthemums in containers of media amended with composted municipal sewage sludge. J. Environ. Hort. 3:53-55.

Gouin, F.R. 1991. The need for compost quality standards. Biocycle, J. Waste Recycling. 32:44,47.

Gouin, F.R. and J.M Walker, 1977. Deciduous tree seedling response to nursery soil amended with composted sewage sludge. HortScience 12:45-47.

Hoitink, H.A.J. Y. Inbar, and M.J. Boehm, 1991, Status of compost-amended potting mixes naturally suppressive to soilborne diseases of floricultural crops. Plant Dis. 23:869-873.

Korcak, F.F., F.R. Gouin, and D.S. Fanning. 1979 Metal content of plants and soils in a tree nursery treated with composted sludge. J. Environ. Qual. 8:63:68.

Marcotrigiano, M., F.R. Gouin, and C.B. Link. 1985 Growth of foliage plants in composted raw sewage sludge and perlite media. J. Environ. Hort. 3:98-101.

Purman, J. and F.R. Gouin. 1992 Growth response of potted plants and transplants in media from processed garbage and sewage sludge. J. Environ. Hort. 10:52-54.

Sanderson, K.C. 1980. Use of sewage-refuse compost in the production of ornamental plants. HortScience. 15:15-20.

Shanks, J.B. and F.R. Gouin. 1984. Using compost in the root medium for roses. BioCycle, J. Waste Recycling 25:29-31,

Vega-Sanchez, F., F.R. Gouin, and G.B. Wilson, 1987 The effects of curing time on physical and chemical properties of sewage sludge and on the growth of selected bedding plants. J. Environ, Hort. 5:66-70.

Wootton, R.D., F.R. Gouin, and F.C. Stark, 1981. Composted digested sludge as a medium for growing annuals. J. Amer. Soc. Hort. Sci. 106:46-49. 